\title{
Designer's role In creating sustainable Communities - Town of Clarington As A Case
}

\author{
Janaka Wijesundara ${ }^{1}$
}

Built - Environment - Sri Lanka, Vol. 11, Issue 01 : 2012: 14 - 20

\begin{abstract}
Summary
Community sustainability, particularly the key aspects of socio-cultural components seem to be less considered in the current planning and development in today's context. This has created issues in our communities which impacts the overall achievement of the sustainability tasks. In this context, urban design can play a major role for the creation of sustainable communities while addressing the socio-cultural interests' in-addition to the environmental sustainability concerns. This paper will provide an overview of the significant issues of sustainability in Canadian sub-urban communities and explore the urban design strategies used to deal with community sustainability issues focusing the town of Clarington in Ontario as a case study.
\end{abstract}

\section{Introduction}

The term sustainability today has acquired the top attention. Yet much focus on its full meaning seems to be restricted exclusively to the areas of environmental sustainability. The sustainability of today has been mainly recognised trough certain type of indicators only, such as climate change, global warming, energy crisis, water and air quality, greenhouse gas emissions, poverty, economy, health, education, natural hazards, etc (United Nations, 2007).

Indicators such as depression, ethnic disparities, violence, crime rates, mental frustration, loss of community identity, community sharing, Social wellbeing, quality of life, cultural integrity and diversity are mostly disregarded and become overlooked dimensions in today's contexts of sustainable developments. There is general agreement that the different dimensions of sustainable development (e.g. social, economic, environmental and institutional) have not been equally prioritized by policy makers within the sustainability discourse (Drakakis Smith, 1995; Burton, 2000).

The developed countries have aggressively adopted the green building agenda to control their high energy consumption from the building sector. Today green building concept, the LEED rating system and Energy Star Standards are the key assessment tools in this regard. Many fields including architecture, planning, and construction industry seem to be revolving primarily around the environmental sustainability as required for the above mentioned ratings.

This results in sustainable architecture and design is being predominantly reasoned out through technological values with far less attention given to the community based components unique to the social and cultural milieu in a community. The town or the community may lose its identity due to the styled or branded designs, or the type of imposed uses or perhaps due to the replacement of key building components by completely aliened ones as maybe required for them to be "green".

Can such communities be sustained? Should this factor be dealt with appropriately by each discipline? What would be the role of urban design in impacting their com- munity sustainability, the continuity and reinstatement of social and cultural features? Can this be done?

This paper will provide an overview of the contemporary socio-cultural sustainable trends in Canada especially focusing securing of the community identity in Ontario suburban centres. This will illustrate the urban designers responses to the town centre community sustainability, discussing the case study of Town of Clarington with the objective of sharing lessons learned in Canadian suburban communities.

\section{Understanding Sustainability}

The interdependency of the activities and happenings of animals and plants creates the equilibrium towards a sustainable planet. In this, the building of environments of animals and plants is seen as a natural phenomenon, whereas the building of human's environments is seen as manmade. However, the strong relationships between man and nature conceived as a deep reciprocal involvement in traditional societies for centuries and they had a sustainable living pattern.

Sustainability is often defined as "meeting the needs of today without compromising the ability of future generations to meet their own needs" (The Brundtland Commission, 1987). The sustainability concept considers four key areas of environmental, social, cultural and economic elements. Decisions made and actions taken in any of the elements of the sustainable development affects the others thus sustainable approach is intended to simultaneously incorporate social, environmental and economic values in to the development decision-making (Tyler, 2000) and concerned with the connections needed between each of them with the implied balance of these four interests.

\section{Social and Cultural Sustainability}

Culture is the aspects of our human natures, our subjectivities, our shared knowledge (Lederach, J.P. 1995) meanings and our memories. Culture is the bond of similarity ('identity') that grounds our sociability (International Journal of environmental, cultural, economic and social sustainability, 2006). It is also the multilayered combinations of which forms persons in the plural: It is ways of seeing, ways of thinking, ways of meaning, ways of relating to each other and ways of connecting with nature. Society is our systems of regulation and governance. Socio cultural sustainability is about how individuals, communities and societies live with each other and set out to achieve their objectives of development models.

Today the socio- cultural values, the aspects such as cultural identity, social uniqueness, ethnic distinctiveness, sense of place, community belongingness have been severely affected within the process of globalisation (Butterworth lain, 2000). The unique crafts and technology also have been affected due to this (Beamer, $\mathrm{J}$ 2009). It is often seen that culture needs to be protected from globalization and market forces, as many see that 
individual communities will lose their cultural identity, traditions, and languages to dominant ideals and cultural components (Duxbury, N, and Gillette, E, 2007). Global change resulting from the industrial economy is affecting the web of life. In response to these concerns, sustainability discussions focus on education, community development, and locally based policies that are consistent with the cultural values of the community. Though the list of priorities, grouped according to the primary dimensions of sustainable development, as identified by United Nation's Division for Sustainable Development, includes the cultural heritage, it does not provide detailed indicators to assess the social and cultural matters (United Nations, 2007).

In a way, today the development fields including architecture are experiencing a design crisis, with clients ranging from private owners to cities demanding that builders and design professionals prioritize sustainability (yet not necessarily socially and culturally) above all else. Though many Green qualified buildings include various sophisticated technical and mechanical system designs, they seem often architecturally less innovative, socially not recognisable and culturally less significant. The aspects of creating more socially cohesive and culturally responsive architecture and developments which essentially embody the cultural components will be revealed as a key to the sustainability while addressing the global trends.

\section{Challenges and New Trends of Social and Cultural Sustainability In Canada}

In Canada, almost 80 per cent of the population is urban. Therefore, a shift towards more sustainability must take place at the local level, in the places where people live, work, and shop (The sustainability Report, 2004).

The major cities in Canada are significantly characterized with immigrant population therefore they are demographically diverse, socially and culturally as well. Assessing the sustainability of Canadian communities means considering not only traditional socio-economic measures of quality of life, but also measures of environmental quality and quantity.

National Round Table on the Environment and the Economy recognizes that "sustainability must be communityled and consensus-based because the central issue is will, not expertise; only a community-based process can overcome the political, bureaucratic and psychological barriers to change. But citizen-led processes must be complemented by top-down government support because it is still only governments that have the regulatory powers to secure the transition to sustainable development" (National Round Table on Environment and Economy).

\section{Issues and trends}

Cities as well as in adjacent regions and suburbs in Canada are often criticized as having urban sprawling, lowdensity development; over-use of non-renewable natural resources; social inequities, poverty and economic hardship; and pollution of air, water and soil (Canadian Institute of Planners, 2006).

Canadian cities including cities and suburbs in Ontario are battling to cope and survive in the face of rapid growth, or even more issues with urban decline. Their Cities are often places of social, economic and environmental extremes and social issues are multifaceted and complex. Generally the new developments mostly tend to create conflicts with the existing communities and their social and cultural sustainability become questionable. Some key issues on the areas of social, cultural community sustainability mainly concerned with designer's scope recognized in Canadian sub-urban communities are:

1. Lack of identity in newly built communities (Urban Times, 2011) and loosing of identity in existing towns

2. Architectural monotony, prototype designs, lack of creativity, non-regionalised architecture

3. Lack of sense of place, typo/repetitive streets, and accessibility (The World Urban Forum 2006)

4. Unsustainable sub-urban form and settlements Trevor Hancock, 2000)

5. Need for creation of safe and well designed communities(Trevor Hancock, 2000), healthy communities

6. Decay of suburban centers/old downtowns due to new town centre commercial developments

7. Forming Ethnic enclaves, ghetto communities (Walks Alan and Bourne Larry S., 2006)

8. Demolition of historically important buildings

9. Gentrification, evicting of inhabitants from old neighbourhoods (Casselman, William, 2008)

10. Isolated sub-urban communities; The native com munities and their cultural differences and social barriers (the World Urban Forum 2006)

It is seen that some developments can be environmentally sound, but might completely destroy the local economies or the important aspects of social and cultural life. At the same time the arrival of power centres in to the traditional downtowns negatively impacts on the local businesses of their communities. The City of Greater Sudbury in Ontario is an example for the small scale retailer's confrontations with the entry of mega retailers within the town centre (Virchez, Jorge and Cachon, Charles, 2004).

\section{Responses to the issues}

For a community to function and be sustainable, the basic needs of its residents must be met. A socially sustainable community must have the ability to maintain and build on its own resources and have the resiliency to prevent and/or address problems in the future. (City of Vancouver, 2005: 12)

The following twelve principles, proposed by the Ontario Round Table on Environment and Economy, include the social, economic, environmental and decision-making aspects of sustainable communities: (Ontario Round Table on Environment and Economy)

A sustainable community is one which

1. Recognizes that growth occurs within some limits and is ultimately limited by the carrying capacity of the environment

2. Values cultural diversity, promotion of ethnic diver sity (Institute On Governance For The Transforma tions Program, 2001) 
3. Has respect for other life forms and supports biodi versity

4. Has shared values amongst the members of the community (promoted through sustainability education)

5. Employs ecological decision-making (e.g., integration of environmental criteria into all munici palgovernment, business and personal decision - making processes)

6. Makes decisions and plans in a balanced, open and flexible manner that includes the perspectives from the social, health, economic and environmen tal sectors of the community

7. Makes best use of local efforts and resources (nurtures solutions at the local level)

8. Uses renewable and reliable sources of energy

9. Minimizes harm to the natural environment

10. Fosters activities which use materials in continu ous cycles. And, as a result, a sustainable community:

11. Does not compromise the sustainability of other communities (a geographic perspective)

12. Does not compromise the sustainability of future generations by its activities (a temporal perspective).

The good suburb must not be the result of sprawl, as seen in many North American suburban communities today. It is, however, self-sustaining in a regional context. It does not deplete resources from the surrounding region without a mechanism for replenishing them, and it works collaboratively with other communities to ensure longterm regional viability (Simmons B. Buntin, 1997).

A good suburb should be a pedestrian oriented area and with mix users of residential, commercial, public and civic activities. It should also offer variety of housing types, buildings and public places with a sense of place mostly with architectural forms which respect to the community identity and history.

A sustainable community is defined as a community or group of connected individuals that employ sustainability principles in their activities that create or contribute to the functioning and existence of their community. In order to create sustainable communities, one should follow the principles and strategies and in implementation, the role of designer has an important task.

Some of notable urban intensification projects done under the flag of suburban community sustainability are (Canada Mortgage and Housing Corporation);

1. London Lane is a 105-unit townhouse project in an old suburban area of Guelph

2. Parkside Mews is a residential infill project of 31 freehold townhouse units, six condo apartments and eight small commercial units with residential units in Ottawa

3. Portland Park Village is a residential infill project in downtown Toronto

4. Seagram Lofts is adaptive reuse of a brown field site, which created residential property in the heart of Waterloo's downtown core from two, heritage, whisky-barrel warehouses

Many Canadian cities and suburban centres are working hard to preserve the quality of community life. For instance, the City of Toronto is planning to be a world leader in sustainable urban living in the year 2025 (City of Toronto, 1999). These cities promote cultural significance which can be clearly seen in different ethnic communities. In Toronto the communities such as little Italy, China Town, Cabbage Town, Rosendale etc are notable. Regent Park low income neighbourhood revitalisation project in east downtown of Toronto, implemented by Toronto Community Housing Corporation is an example for locally based, comprehensive, community building strategies to achieve sustained economic and social neighbourhood transformation.

The artists use neighbourhoods to create their art works which stimulates the identity of towns socially and culturally. Street arts, public arts, street performances improve the beauty and quality of neighbourhood places adding life. For instance, to support this idea in the City of Toronto, $1 \%$ of the development costs to be paid to the city for implementation of public art projects (City of Toronto, 2009). Some downtowns have specially created urban quarters or districts. An example for this is that the entire district on Spadina Street in Toronto has been converted to an area with businesses, offices and studios related to art. This kind of approaches are seen in a number of smaller towns and suburban town centres where urban design has played a greater role in creating sustainable town centres. The towns of Port Hope, Port Perry, Cobourg, East Gwillimbury and Newmarket are some example from Greater Toronto area.

The contemporary chains of grocery stores popular in many countries have created negative impact on traditional Canadian suburban centres and among their communities. Due to the enormous size of these stores in neighbourhoods, they have been re-introduced in a much friendly form as Neighbourhood Markets with newly introduced form of design and materials showing intimacy and blending with the local settings and flavour. For instance, Wal-Mart opened three neighborhood type stores in 2006 from which one is in London, Ontario, and two are in the Greater Toronto area.

\section{Towards A Sustainable Town Centre Community -} Town of Clarington As A Case

Like many sub- urban communities around Canada, the town centre of Clarington in Ontario is a traditional residential and commercial center. People visit the centre for banking, to shop for cloths, to eat in the restaurants or for doctors or hairdresser's appointments. There are no complicated activities, or large shopping malls or huge office complexes in the town centre.

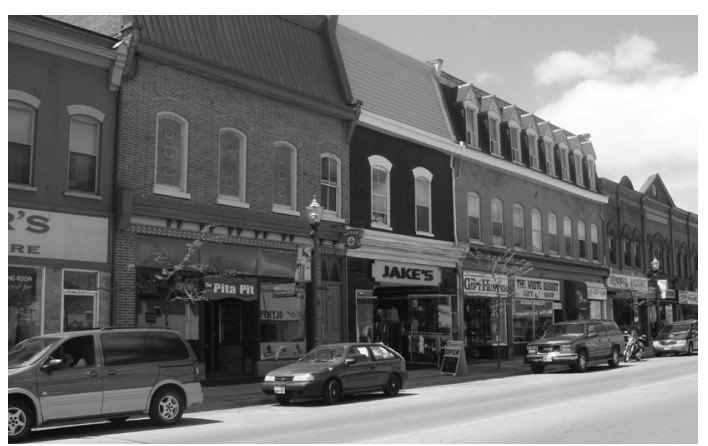

Historic town centre, Town of Clarington, Ontario

Photo Credit: Author

Issues and challenges faced

For more than 10 years, the existing historic town centre has been challenged by the development of a new town area and the general trend towards decentralization from the core. During the end of 1990s, the town experienced growing of residential population over spilled from Toronto and creation of more cohesive and attractive living opportunities was a task of the town. However, by 2000 , the town's business and investment community felt that the erosion of investment and interest in the historic town had continued to slip and this affected the town's sustainability. 


\section{Early Design and Planning Interventions}

Responding to the situation, a number of key urban design and planning related interventions were carried out during the years of 2000 to 2004 mainly by the Town of Clarington:

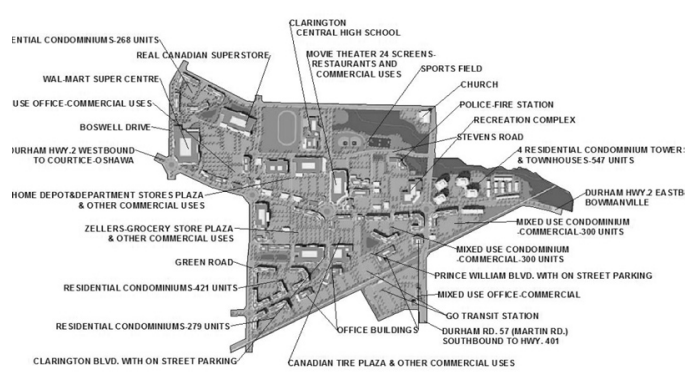

Clarington West Town Centre Development Master Plan, Source: Planning Services Department, Town of Clarington

\section{a) Revised the Downtown Official Plan Policy and zoning regulations}

Understanding the up-coming issues, the Town took the initiation of revising the Official Plan Policies and zoning regulations. Many of such changes were expected to do mainly through the commercial policy review which focussed the traditional down town and the new town.

\section{b) Free parking Policy}

Since 2003, Town adopted the free parking policy in all municipally owned parking lots within the old town centre. The three hours free parking was attracted by many shoppers and tourists.

\section{c) King Street improvement project}

The King Street improvement project completed in 2004 involved the replacement of existing sidewalks with a historically authentic design with pavers and other infrastructure improvements such as traditional type street lights and street furniture, was significant in improving the town character. The urban design input has become the key strategy to improve and enhance the street character of the conventional town centre.

\section{d) Public Art Program}

Town and the business community believed that the town's character improvement is important to attract shoppers and local and foreign visitors. A downtown wide public art program was implemented improving the neglected areas of the town, specially for vacant sites and uninteresting buildings façades. It is a culturally sensitive idea to install large murals depicting the history of the places with their original view of such places. A number community based organisations were involved with the Municipality in this program.

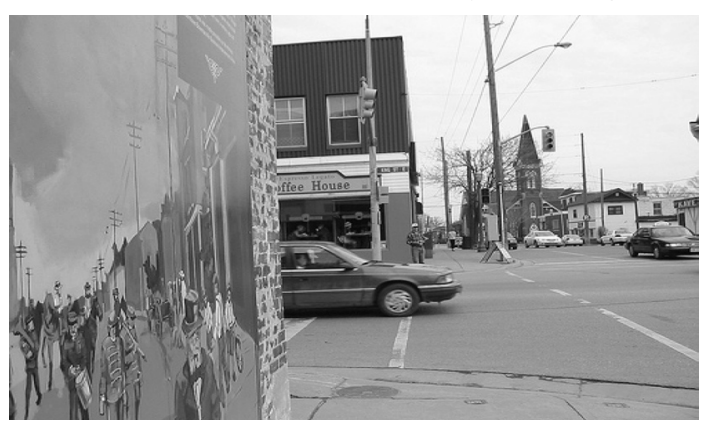

Clarington town centre murals, implemented under Public Art Program improve the town's historic authenticity, Photo Credit: Author

\section{e) Providing new amenities}

The town's public park with facilities such as raised stage, toilets, and a public gathering place with a shelter was built with landscaping features. This is widely used by the people of the community for various social events, music, dramas, meetings and festivals through the year.

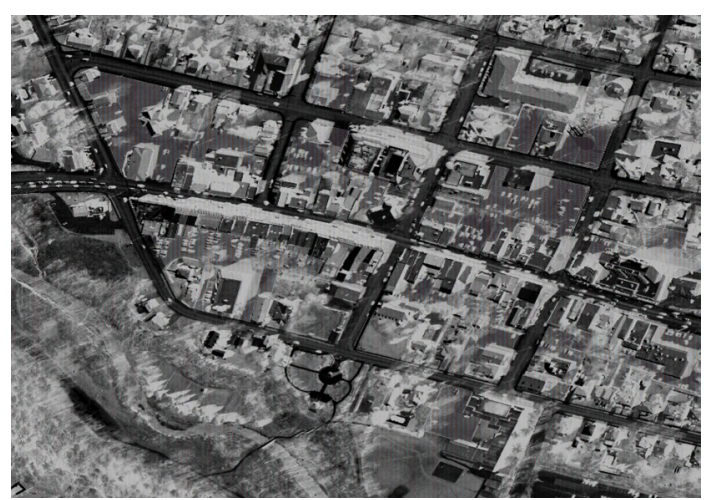

Identified areas for the creation of new parking and rear commercial streets in Historic Downtown

Source: Planning Services Department, Town of Clarington

In 2006, as per the recommendations of the Commercial Policy Review (Planning Services Department, 2006), with lot of pressures from the town's business community, the Town Council approved the proposed development projects in the new West Town Centre. This is a development of a massive area of more than 100,000 sqm of commercial spaces with power centres with more than 2500 parking spaces altogether. With this proposal, the old downtown business community faced a serious threat on continuing their business. In response to this, Town came up with a number of key design and planning interventions to improve the town's functions and character.

Solutions, recent actions and urban design initiations

As a response to the request of the Downtown Business Community, the City Council approved the preparation of a Community Improvement Plan (CIP) for the affected area in 2003 and a community focus group guided the study to its completion in June of 2005 (Planning Services Department, 2005).

The overall plan comprised several types of parallel programmes, design interventions and implementation strategies:

\section{a) Heritage Building Façade Improvement Grant Program}

This Program is intended to assist property owners with the financing of heritage building façade improvements. Many of these owners were losing their businesses and were unable to finance on building construction or renovation works. The grant covered up to one third of the costs of the eligible work per building to a maximum of $\$ 10,000$ per municipal street address or storefront. The urban design staff continuously assisted the building owners by preparing the basic guide designs for the façade improvements and infill developments. The owners were provided guidance free of charge. When improving the old building's façades, the original character of the building was referred to using old photographic records in the town's archives. However, the contemporary requirements such as services, materials, new technology were also considered as important data. 

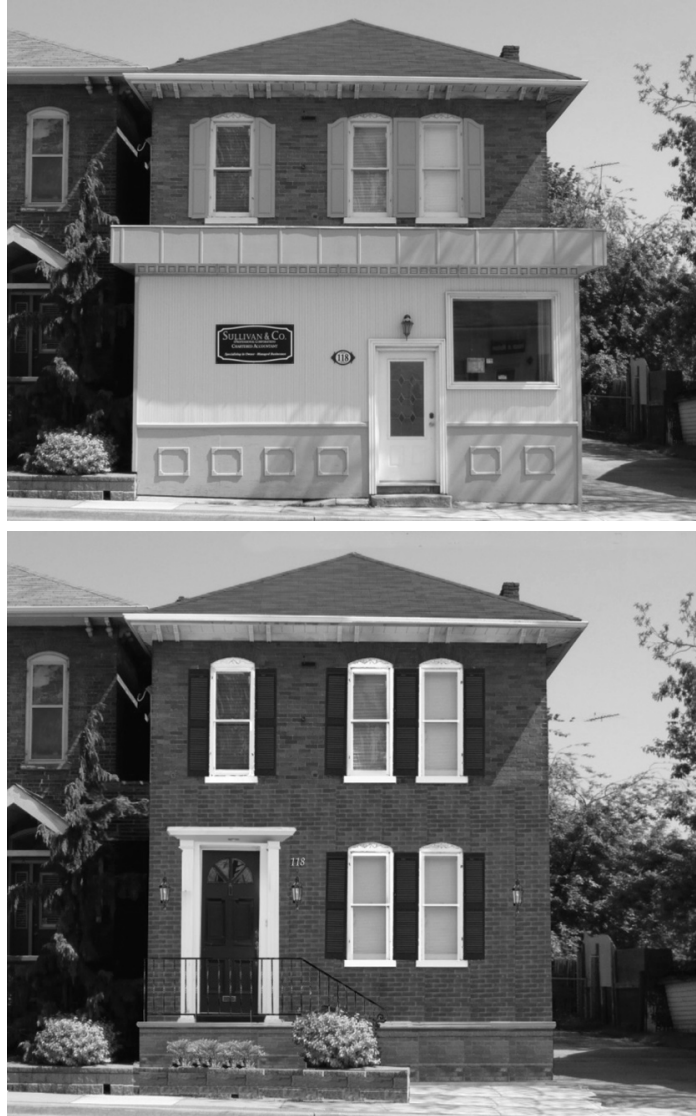

No 118, King Street. Existing situation of the building (above) and same with façade improvement (below) under the Grant Program, Photo Credit: Author

\section{b) Upgrade to Building Code Grant Program}

This program is intended to assist property owners with the financing of building improvements required to bring existing older buildings into compliance with the current Ontario Building Code. The grant covers up to one third of the costs of the eligible work per building to a maximum of $\$ 5,000$

\section{c) Building Permit Fee Grant Program}

Through this program the property owners are assisted with financing the cost of the development process by providing a Grant to offset the amount of the applicable Building Permit Fee to a maximum of $\$ 3,000$.

\section{d) Site Plan Control Fee Grant Program}

This is to assist commercial property owners with financing the cost of the development process by providing a grant to offset the amount of the Site Plan Control Fee to a maximum of $\$ 3,000$

\section{e) Increase of the car parking facilities}

The back lane parking is a new design idea of utilising rear of the commercial premises in the downtown area. The customers are allowed to access and park the cars at the rear which contributes to ease the traffic flow on the main streets.

\section{f) Town's character improvement}

While some are major capital works such as the King Street bridge reconstruction others are recommendations about promotion and events of the town's community.
The urban design input was provided for the design of bridge elements such as side walls, bridge lighting, flower baskets, flags and banner hangers. Most of these details preserved the character of the old bridge. Additionally, the wider sidewalks were introduced with unique surface designs and bicycle lanes were proposed.

The urban design played a key role in improving the street character of many areas, specially the east end of the centre where many buildings dating from 1950s are located far from the street while locating large car parks next to the street. King Street East Corridor Urban Design Study of 2004 (Planning Services Department, 2005 ) identified many community related issues with regard to the character and functionality of the area and its recommendations such as bringing the built edge to street and designs responding the street intersections and corners incorporated in granting the development approvals of all the projects along this area.
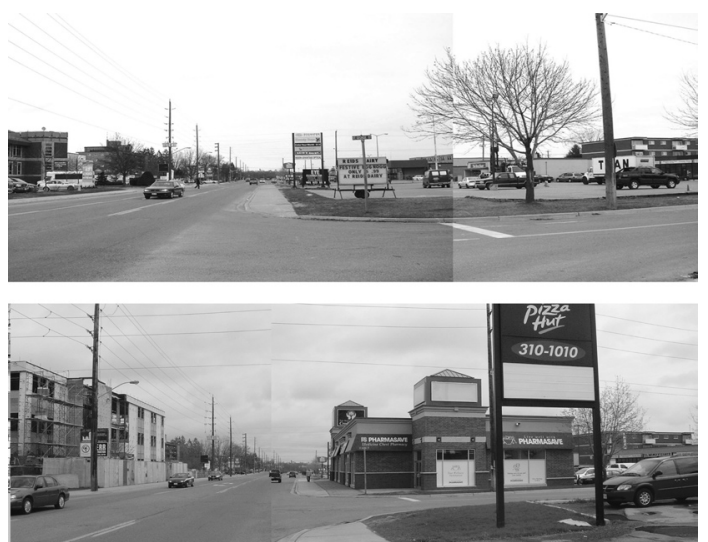

Clarington Downtown -The Urban Design efforts to bring the built edge to the King Street front. This Shopping block at the eastern edge of the downtown was constructed in 2006 as per the east town area urban design framework Plan. Photo Credit: Author

\section{g) Other community based programs}

In parallel, several community initiated programs were launched with the assistance and direction of the Town Council. Valleys 2000 is a non-profit, community-based volunteer organization dedicated to the rehabilitation and environmental enhancement of quality of urban parklands and trail systems in the two valleys within the town.

\section{Making changes happen}

At a broader level, the implemented community improvement plan has helped to re-create the pride of ownership downtown and to re-establish the cultural identity. The façade improvements and building refurbishments helped to support a renewed sense of place. Several notable buildings have been reoccupied and put back into use. The recently completed infill developments specially along King Street conform to the existing street character.

With its improved trails and walking paths, it is a destination for many visitors year round. Construction of new steps down to the valley as well as a footbridge across the creek ensured public access to Bowmanville Valley from the heart of downtown. In the third year of town's Community Improvement Program, 48 applications have been received and 20 projects have had been completed by 2010 . 
There has been good response and participation throughout the Community Improvement Program implementation. The public and various other agencies involved in the preparation of project visioning and implementation.

The shop owners and other stake holders were provided assistance on projects and technical knowhow by the urban designer of the town, and they are pleased with the program and progress made. Specially, the Town Council was highly impressed on the results and all councillors decided to support the program ensuring continues funding.

\section{Conclusion}

This case study shows that the community sustainability requires:

- To have a clear concise community vision plan

- Demonstrate long term commitment and effective implementation strategies

- To have upfront consultation, community participa tion and involvements

- To have well structured and combined incentive programs to support it, as the community rebuild ing is more risky compared to green field develop ments

- To understand and cater to the social, cultural and community values, aspirations and objectives

Town's community sustainability will require agreeing on a concise vision and that should be backed by a number of minor plans, actions and programs identifying implementation strategies for each of them. While many teams are involved in this process, there may be a few key professionals who could conduct the program and manage the implementation. As seen here, the urban design can engage in an influential role throughout this process and lead to its success.

The community sustainability should be considered as an important element of overall sustainability concept. Recent trends emphasize that the social and cultural aspects are being incorporated for their green rating criteria. For an example, Sri Lanka, the Green Rating System includes a separate criterion for social and cultural awareness (Green Building Council Sri Lanka 2011). The success of the community sustainability is assessed not only in terms of the environmental and technological reasons but also with the intangible aspects such as community pride, ownership, belongingness, cultural identity, sense of place, community sharing, community glue, community resilience, integrity and diversity. Therefore developing effective assessment tools for the purpose of evaluating the progress and successes of such aspects of social and cultural sustainability would be an important task

\section{Bibliography}

Andrea Colantonio (2008). Traditional and Emerging Prospects in Social Sustainability, working pa per, Oxford Brookes University.

Beamer, J. 2009. Reviving Japanese "Traditional" In dustries: Prospects and Strategies for Asian Regional Integration, Draft Paper, GIARI Sum mer Institute, Interdisciplinary Studies - Mate rial Culture/Sociology, University of Alberta, Canada

Biart, M. (2002) 'Social sustainability as part of the so cial agenda of the European community', in Ritt, T. (Ed.): Soziale Nachhaltigkeit: Von der Umweltpolitik zur Nachhaltigkeit? Arbe iterkammer Wien, Information en zur Umwelt politik 149, Wien, pp.5-10. Available at http://wien.arbeiterkammer.at/pictures/importi ert/Tagungsband 149.pdf

Brent Gilmour, John Warren (2008). The New District Energy: Building Blocks for Sustainable Com munity Development, The Canadian District Energy Association (CDEA), Toronto Atmo spheric Fund (TAF) and the Canadian Urban Institute (CUI),

Butterworth lain, 2000. The Relationship between the Built Environment and Wellbeing: Victorian Health Promotion Foundation, Melbourne, Australia

Canada Mortgage and Housing Corporation, http://www.cmhc-schl.gc.ca/en/inpr/su/ sucopl/sucopl_003.cfm

Canadian Institute of Planners, (2006), the World Ur ban Forum 2006, Vancouver Working Group, Discussion Paper, Canada

Canadian Public Health Association (1992). Human and Ecosystem Health. Ottawa: CPHA. Casselman, William, 2008, Canadian World of the Day, March 2009 Update, BC, Canada

City of Toronto (2009), Toronto Official Plan, City of Toronto

City of Toronto (1999), City of Toronto environmental task force education and awareness work group final report September 27, 1999. City of Toronto

City of Vancouver (2005), A Social Development Plan for the City of Vancouver: Moving Towards So cial Sustainability, Administrative Report A7, Vancouver

Duxbury, N, and Gillette, E, (2007); Culture as a Key Dimension of Sustainability: Exploring Con cepts, Themes, and Models, Working Paper No 1, Centre of Expertise of Culture and Com munities, Canada

Drakakis-Smith D. (1995), "Third World Cities: Sustain able Urban Development, 1", Urban Studies, Vol. 32, Nos 4-5

Egan, J., (2004), The Egan Review: Skills for Sustain able Communities, ODPM, London

Green Building Council Sri Lanka 2011.Green Rat ing System for Built Environment, Version 1, Green Building Council, Sri Lanka

Institute on Governance for the Transfor

mations Program, 2001. Ethnic communities in Cana da from a governance perspective: unity in di versity? Institute on Governance, University of Indiana

International Journal of environmental, cultural, eco nomic and social sustainability 2006; Proceedings of First International Conference on environmen tal, cultural, economic and social sustainabil ity in February 2005, Hawaii www.Sustainabil ity Conference.com 
Lederach, J.P. (1995). Preparing for peace: Conflict transformation across cultures. Syracuse, NY: Syracuse University Press.

Joanne Di Sano (2001). Indicators of Sustainable De velopment: Guidelines and methodologies; Di vision for Sustainable Development, United Nations,

Jon Hawkes, (2001). The Fourth Pillar of Sustainabil ity: culture's essential role in public plan ning,Common Ground P/L, Melbourne.Kelly Hawke Baxter and Mike, Purcell, Commu nity Sustainability Planning, Municipal World, November 2007

National Round Table on Environment and Economy, Ottawa, Ontario, Canada Web: www.nrtee-trnee.ca

\section{Ontario Round Table on Environment and} Economy, http://www.globallearningnj.org/ global_ata/a_vision_of_community_sustain ability.htm

Osberg, Lars (1990). Sustainable Social Development (mimeo). Halifax, N.S.: Department of Eco nomics, Dalhousie University.

Planning Services Department 2010, Orono Commu nity Improvement Plan Grants Update, Plan ning Report PSD-0002-10, General Purpose and Administration Committee Meeting on January 04,2010 , Municipality of Clarington, ON, Canada

Planning Services Department 2010, Bowmanville Community Improvement Plan Grants Up date, Planning Report PSD-0003-10, General Purpose and Administration Committee Meet ing on January 04, 2010, Municipality of Clar ington, ON, Canada

Planning Services Department, 2006, Commercial Policy Review, Planning Report COPA 2005006, Municipality of Clarington, ON, Canada

Planning Services Department, 2005, Bowmanville Community Improvement Plan, Municipality of Clarington, ON, Canada
Simmons B. Buntin (1997), Community Redeveloped Redeveloping Suburban Downtowns for a Sustainable Future, Unpublished Document, Urban and Regional Planning Program, Col lege of Architecture and Planning University of Colorado, Denver

The sustainability Report (2004), Sustainability Re porting Program; http://www.sustreport.org/is sues/sust_comm.html

Trevor Hancock (2000), Healthy Communities Must Also Be Sustainable communities, Public health reports March/April \& May/Jun e 2000, volume 115, Canada

Tyler, M.E. 2000. The ecological restructuring of urban form. In Canadian cities in transition. 2nd edi tion; In Canadian cities in transition.2nd. Edi tion, eds. T. Bunting and P. Filion. Toronto: Ox ford University Press

United Nations. (1987). Report of the World Commis sion on Environment and Development, Gen eral Assembly Resolution 42/187, 11 Decem ber 1987

United Nations (2007). Indicators of Sustainable Development: Guidelines and Methodologies; United Nations publication, New York

Urban Times, 2011. Reinventing Suburbs: Big Gestures or Small Steps? http://www. theurbn.com/2011/02/reinventing-suburbsbig-gestures-small-steps/

Virchez, Jorge and Cachon, Charles (2004), The im pact of mega-retail stores on small retail busi nesses; The case study of Sudbury in north ern Ontario, in Canada, pp. 49-62, Revista Mexicana de Estudios, Asociacion, Mexicana de Estudios Sobre Canada, ISSN 1405-8251 Mexico

Walks Alan and Bourne Larry S., 2006. Ghettos in Canada's cities? Racial segregation, eth nicenclaves and poverty concentra tion in Canadian urban areas. The Canadian Geographer / Le G'eographe canadien 50, no 3 (2006) 273-297 